\title{
Millennial-Scale Climate Variations During the MIS3 in the North Piedmont of the Kunlun Mountains, China
}

\author{
Fengnian Wang ${ }^{1}$, Baosheng $\mathrm{Li}^{2,3 *}$, Dongfeng Niư ${ }^{4}$, Xiaohao Wen², Zhiwen $\mathrm{Li}^{5}$, Yuejun Si ${ }^{6}$, Yihua Guo ${ }^{7}$, Zhiying Yang ${ }^{1}$ and Enbo Liu ${ }^{1}$ \\ ${ }^{1}$ School of Geography and Tourism, Huizhou University, Huizhou 516007, China \\ ${ }^{2}$ School of Geography, South China Normal University, Guangzhou, 510631, China \\ ${ }^{3}$ State Key Laboratory of Loess and Quaternary Geology, Institute of Earth Environment, Chinese Academy of Sciences, Xi'an, 710061, China \\ ${ }^{4}$ Physical Science and Technology School, Lingnan Normal University, Zhanjiang, 524200, China \\ ${ }^{5}$ College of Earth Science, East China Institute of Technology, Nanchang, 330013, China \\ ${ }^{6}$ School of Geography and Planning, Guangxi Teachers Education University, Nanning, 530001, China \\ ${ }^{7}$ Guangzhou Institute of Geography, Guangzhou, 510070, China
}

\begin{abstract}
According to the analyses of grain size and major element distribution in the Aqiang loess section AQS3 in the north piedmont of the Kunlun Mountains in China, the peaks and valleys in the loess and loess-like sandy sedimentary facies displayed clear variations in their mean particle diameter, standard deviation, $\mathrm{SiO}_{2}, \mathrm{Al}_{2} \mathrm{O}_{3}, \mathrm{TOFE}\left(\mathrm{Fe}_{2} \mathrm{O}_{3}+\mathrm{FeO}\right)$, and $\left(\mathrm{Al}_{2} \mathrm{O}_{3}+\mathrm{TOFE}\right) / \mathrm{SiO}_{2}$ ratio. Both grain size and major element distributions showed 19 cycles of alternation among the sedimentary facies. Results suggested that the observed cycles mainly resulted from fluctuations between the coldarid and warm-humid climates. Most warm periods in the AQS3 corresponded well to the D/O events recorded by the ice-core oxygen isotope in the GRIP during the MIS3. This study suggests that high-frequency climatic fluctuations on millennial scale occur in the north piedmont of the Kunlun Mountains, and they are regional responses to global climate changes during the MIS3.
\end{abstract}

Keywords: Kunlun Mountains; Aqiang loess section; MIS3; Major elements; Millennial-scale climate fluctuations

\section{Introduction}

The loess region in the north piedmont of the Kunlun Mountains is an important research area in China. In the early 1890s, Russian geologist Obruchev AV investigated the southern part of Xinjiang province and found that the loess belt surrounds the south and north of the Taklimakan Desert, and it extends to the slopes of Kunlun Mountains and Pamir region. He suggested that the loess contains aeolian sand and dust deposit [1]. In the 1960s, some Chinese geologists studied the ages and causes of the loess; they confirmed that this area is mainly aeolian sand, its top is $4000 \mathrm{~m}$ above sea level [2], and its age is mainly within the Malan loess period [3] or Middle-Pleistocene [2]. Since 1980, geologists from China and abroad have continuously studied the loess [4-13], and they obtained ages by ${ }^{14} \mathrm{C}$ and TL [5-8]. They further confirmed that the loess is aeolian [5-8], and the age is within the Malan loess period [11-14]. Several old loess sequences also exist in some places within this area [12], such as in Aqiang, which is located in the north of the Kunlun Mountains. Since 1990, many studies have been conducted in this place, and they found that this loess is an aeolian deposit before the Brunhes epoch. This finding corresponds well to the loess-paleosoil sequence in the Loess Plateau. The position of the $\mathrm{B} / \mathrm{M}$ is inferred on the basis of the analysis regarding the cosmic dust content in the loess strata [15]. Fang et al. studied the loess section in Dabanbai near Aqiang. According to the paleomagnetic analysis, they confirmed that the oldest age of the loess deposit is at the $\mathrm{B} / \mathrm{M}[16]$. On the basis of the analysis of grain size and $\mathrm{CaCO}_{3}$ distribution, they suggested that climate variations within this area indicate the rise of Qinghai-Tibet Plateau, the formation of Taklimakan Desert, and the occurrence, development, and variation of aridity since 7.0 $\mathrm{Ma}$ [17-19]. These findings help us further understand the relations between desert evolution and Asian monsoons.

Previous loess studies were mainly centered on the $10 \mathrm{ka}$-scale climate variations in the north piedmont of the Kunlun Mountains because of the increased mountain and river erosion. Moreover, sediments were thought to be preserved incompletely; thus, few studies on millennial-scale climate changes were reported. The Aqiang section contains a sequence of continuously accumulated aeolian loess and loess-like sand sediments with thickness of $40 \mathrm{~m}$, which corresponds to the Last Interstatial (MIS3). This section also recorded information on millennial-scale climate variations. In the present study, we attempted to understand and confirm the millennial-scale climate variations during the MIS3 in the north piedmont of the Kunlun Mountains by combining the analysis on the lithological characteristics and sedimentary facies in the Aqiang loess section (AQS3) with that of ages, grain sizes, and major elements.

\section{Study Area and Methods}

\section{AQS3 segment}

The Aqiang stratigraphic section is located in an arid valley at approximately $4 \mathrm{~km}$ southwest of the Aqiang village in Yutian County, Xinjiang province of China. The area is located in the interface between the loess-like sandy sediment belt on the southern margin of the Taklimakan desert and the loess belt of the northern piedmont of the Kunlun Mountains $\left(36^{\circ} 28^{\prime} \mathrm{N}, 81^{\circ} 56^{\prime} \mathrm{E}\right)$ with an altitude of $2420-2492.5$ $\mathrm{m}$ (Figure 1). The average annual precipitation, evaporation, and temperature are $170 \mathrm{~mm}, 2590 \mathrm{~mm}$, and $12^{\circ} \mathrm{C}$, respectively. The aridity index is over 16 , which is the maximum value for an extremely arid region. The thickness of the Aqiang section is $72.5 \mathrm{~m}$ and that of the loess and loess-like sandy sediments is $66.2 \mathrm{~m}$. The section overlies the Xiyü Formation $\mathrm{T}_{3}$ terrain that consists of alluvial gravels and sands.

${ }^{*}$ Corresponding author: Baosheng $\mathrm{Li}$, State Key Laboratory of Loess and Quaternary Geology, Institute of Earth Environment, Chinese Academy of Sciences, Xi'an, 710061, China, Tel: 861058805461; E-mail: libsh2013@163.com

Received March 09, 2017; Accepted March 29, 2017; Published April 07, 2017

Citation: Wang F, Li B, Niu D, Wen X, Li Z, et al. (2017) Millennial-Scale Climate Variations During the MIS3 in the North Piedmont of the Kunlun Mountains, China. J Environ Anal Toxicol 7: 455. doi: 10.4172/2161-0525.1000455

Copyright: (c) 2017 Wang F, et al. This is an open-access article distributed under the terms of the Creative Commons Attribution License, which permits unrestricted use, distribution, and reproduction in any medium, provided the original author and source are credited. 
Citation: Wang F, Li B, Niu D, Wen X, Li Z, et al. (2017) Millennial-Scale Climate Variations During the MIS3 in the North Piedmont of the Kunlun Mountains, China. J Environ Anal Toxicol 7: 455. doi: 10.4172/2161-0525.1000455

The AQS3 segment is within 3.2-42.9 $\mathrm{m}$ in the Aqiang section (Photo 1 ); the top and bottom parts of AQS3 are the interfaces of 2LVS/3SL and 18LVS/19L in the section (Figure 2), which mainly consist of interbeddings of grayish-yellow sandy loess and grayish-white loesslike aeolian sandy sediment. Both interfaces are overlapped (Photo 2), loose, evenly sorted, and slightly cemented by calcium, with level to slightly inclining beddings called the halite layers. Given that AQS3 segment possesses relatively even surface, the loess and loess-like sandy sediments are mainly distinguished by grain size and detritus grade. For convenience, we labeled the loess and loess-like sandy sediment in this paper as L and LVS, respectively (Figure 2).

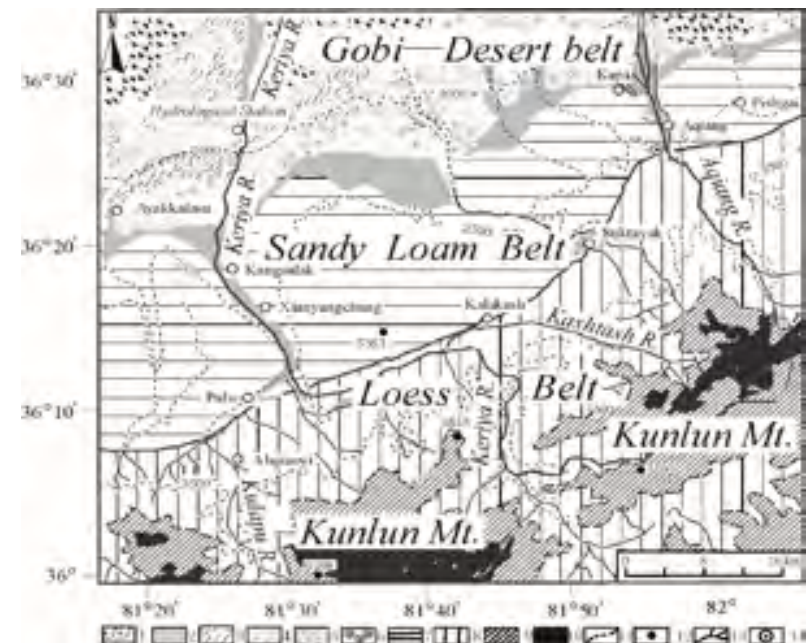

Figure 1: The location of the Aqiang section and main types of aeolian sediments. 1. Gobi; 2. Oasis (forestlands and irrigated farmlands); 3. barchan dunes and barchan dune chains; 4 . longitudinal dunes and barchan longitudinal dunes; 5 . mobile dune sands; 6 . fixed and semi-fixed dune sands; 7 . loess-like sandy sediments; 8 . loess; 9. mountain; 10. ice and snow; 11. contour-line (m); 12. the height above sea level $(\mathrm{m}) ; 13$. River; 14. the location of the Aqiang section.

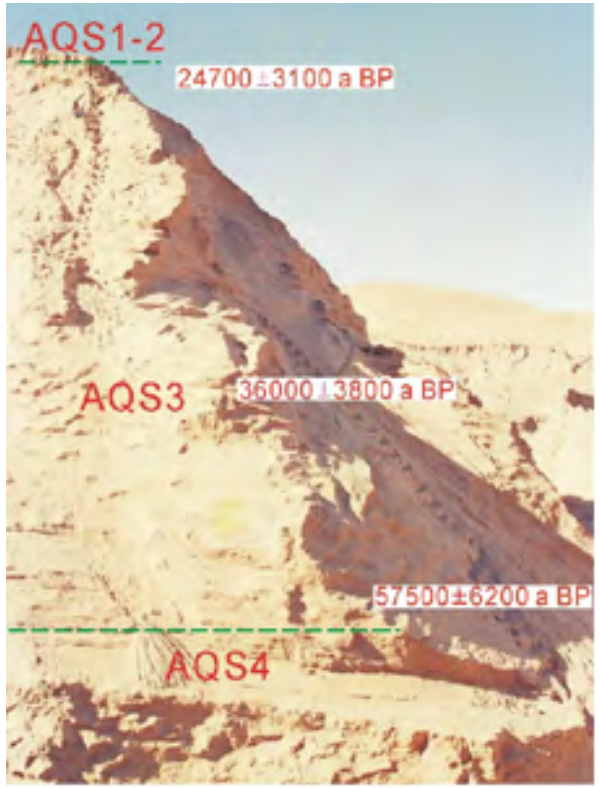

Photo 1: The loess and loess-like sandy sediment in the AQS3 of Aqiang section in the south of Taklimakan Desert.

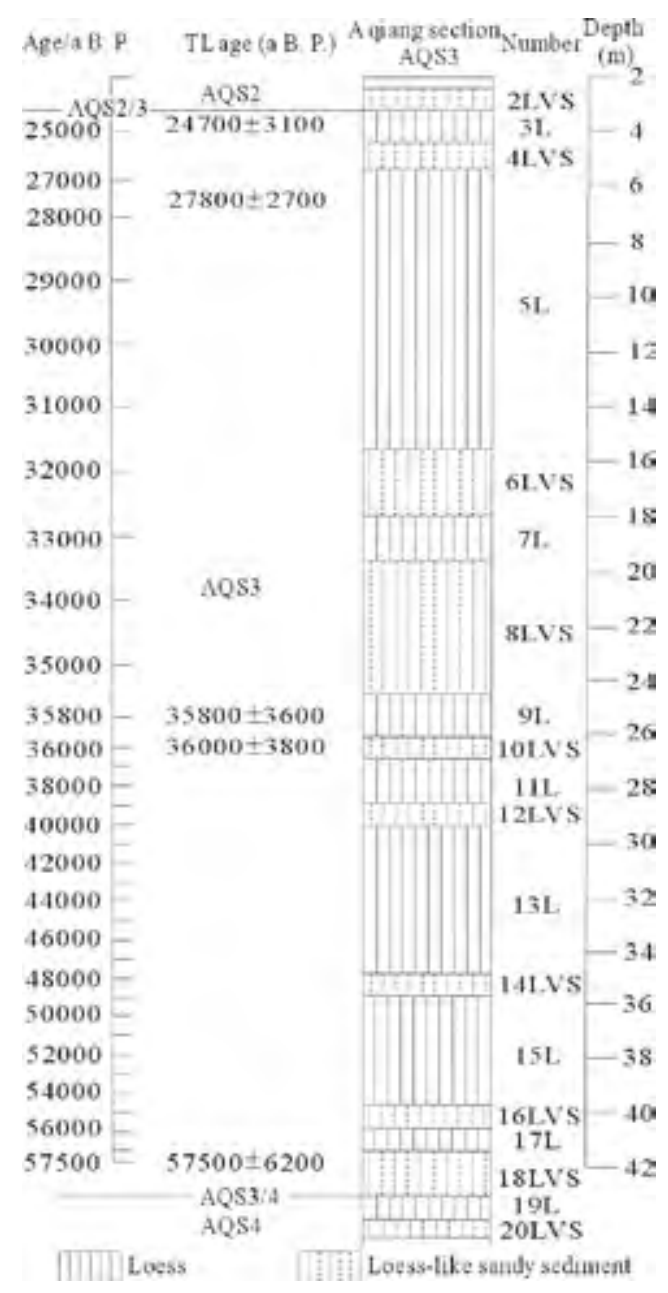

Figure 2: The ages of the AQS3 segment in the Kunlun Mountains.

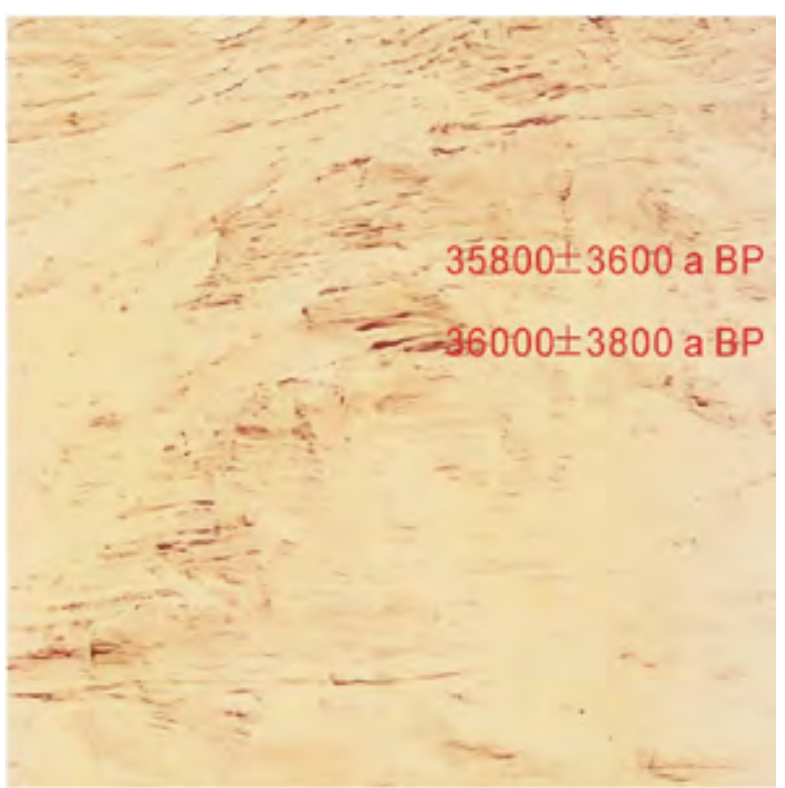

Photo 2: The overlapped loess and loess-like sandy sediments in the AQS3. 
Citation: Wang F, Li B, Niu D, Wen X, Li Z, et al. (2017) Millennial-Scale Climate Variations During the MIS3 in the North Piedmont of the Kunlun Mountains, China. J Environ Anal Toxicol 7: 455. doi: 10.4172/2161-0525.1000455

Page 3 of 6

\section{Methods}

A total of 52 samples were collected at an average interval of $80 \mathrm{~cm}$ (some at an interval of $40 \mathrm{~cm}$ and a depth of 3.2-5.0 $\mathrm{m}$ ) in the AQS3 segment of the Aqiang section. We dated the ages of 3L, 5L, 9L, 10LVS, and 18LVS in the AQS3 segment. TL age determination was conducted by Lu Yanchou at the State Key Laboratory of Seismology of Earthquake Administration Bureau of China and Fei Jingxian at the Institute of Geology and Geophysics, Chinese Academy of Sciences, and a Type 711 age determination instrument (Littlemore Scientific Instrument Corporation, Oxford, UK) and a Type 2000A age-examining equipment (Harshaw Chemistry Instrument Corporation, USA) were used. Dating materials were fine quartz grains with a diameter of 4-11 $\mu \mathrm{m}$ and coarse grains of more than $50 \mu \mathrm{m}$. The total error was $8 \%-11 \%$. The TL ages and relevant parameters are listed in Table 1.

The grain-size experiment was performed using the sifting method at the Central Laboratory of the Cold and Arid Regions Environmental and Engineering Research Institute, Chinese Academy of Sciences. The grain-size grading was based on Wooden-Wentvoice [20] Formation $\Phi=-\log _{2}$ d. Mean particle diameter $(\mathrm{Mz})$ and standard deviation $(\sigma)$ were calculated by using the following formula of Folk and Ward (Folk and Ward 1957): $\mathrm{Mz}=(\Phi 16+\Phi 50+\Phi 84) / 3, \sigma=(\Phi 84-\Phi 16) / 4+(\Phi 95-\Phi 5) / 6.6$.

Major element analyses were performed using a type 3070E X-ray fluorescence spectrometer (Japan). First, $4 \mathrm{~g}$ of the samples were dried at $105^{\circ} \mathrm{C}$, ground and sifted through a 200 mesh screen, and crushed into small pieces of less than 75 um using a multipurpose grinder. Subsequently, the samples were pressed into $32-\mathrm{mm}$-diameter pellets under 30 ton high pressure and then measured in desiccators. The analysis results of major chemical elements were finally computerized.

\section{Results}

\section{Ages of the AQS3 segment}

The top and bottom areas of the AQS3 segment are in the $3 \mathrm{~L}$ and 18LVS, and their TL ages are $24700 \pm 3100$ and $57500 \pm 2570$ a B. P., respectively. Therefore, the age of the AQS3 segment is within 5750024700 a B. P., which corresponds to the MIS3 of 59000-23000 a B. P. in the SPECMAP Curve [21] and the MIS3 recorded by the ice-core isotope in Greenland, GRIP Members [22], North Atlantic Ocean [23], and West Pacific Ocean [24].

Considering the even lithological features and aeolian sediments of the AQS3 segment, we calculated some ages of the layers by using regression of sedimentation rates. The calculated average sedimentary rates are based on three sections and their ages in the AQS3: the first section is from 24700 a to 27800 a with a depth of $380-660 \mathrm{~cm}$ and a sedimentary rate of $90.3 \mathrm{~cm} / \mathrm{ka}$; the second section is from 27800 a to 35800 a with a depth of $660-2540 \mathrm{~cm}$ and a sedimentary rate of $235.0 \mathrm{~cm} / \mathrm{ka}$; and the third section is from 36000 a to 57500 a with a depth of $2645-4180 \mathrm{~cm}$ and a sedimentary rate of $71.4 \mathrm{~cm} / \mathrm{ka}$. On the basis of these average sedimentary rates, we illustrated the millennial scale variations of the AQS3 in Figure 2. Evidently, the time period of the AQS3 corresponds to the MIS3. We labeled the upper and lower interfaces of the AQS3 with AQS2/AQS3 and AQS3/AQS4, and their ages are approximately 23000 and 59000 a B. P., respectively.

\section{Grain-size}

We analyzed the grain size for all 52 samples of the AQS3 segment and summarized the values of $\mathrm{Mz}$ and $\sigma$ in Figure 3. In Figure 3, the $\mathrm{Mz}$ value ranges from $4.24 \Phi$ to $5.13 \Phi$ with an average of $4.58 \Phi$, and the $\sigma$ value ranges from 0.24 to 0.99 with an average of 0.51 . In addition, the Md value ranging from $4.14 \Phi$ to $5.09 \Phi$ is similar. Variations in $\mathrm{Mz}$ and $\mathrm{Md}$ are evidently lower than $1 \Phi$ and that of $\sigma$ is lower than 0.80 . This result indicates that the AQS3 segment is evenly composed. The grain-size chart also shows alternations between the peaks and low values of $\mathrm{Mz}$ and $\sigma$.

\section{Major elements: $\mathrm{SiO}_{2}, \mathrm{Al}_{2} \mathrm{O}_{3}$, TOFE, and $\left(\mathrm{TFE}+\mathrm{Al}_{2} \mathrm{O}_{3}\right) / \mathrm{SiO}_{2}$}

The major elements of 52 samples in the AQS3 were analyzed. Elemental analysis (Figure 3) shows that $\mathrm{SiO}_{2}$ content is the highest at a range of $52.89 \%-65.72 \%$ and an average of $59.62 \%$. Furthermore, the $\mathrm{Al}_{2} \mathrm{O}_{3}$ content ranges from $9.22 \%$ to $10.11 \%$, and the average is $9.73 \%$. The TOFE $\left(\mathrm{Fe}_{2} \mathrm{O}_{3}+\mathrm{FeO}\right)$ content only ranges from $3.38 \%$ to $3.83 \%$ and presents an average of $3.61 \%$. These elements are good paleoclimate indexes to illustrate environmental changes because their total content ranges from $66.51 \%$ to $75.49 \%$. We also calculated the ratio of $\left(\mathrm{Al}_{2} \mathrm{O}_{3}+\mathrm{TOFE}\right) / \mathrm{SiO}_{2}$ to further account for climate variations, and the resulting value ranges from 0.21 to 0.26 with an average of 0.22 .

In Figure 3, the major elements and $\left(\mathrm{Al}_{2} \mathrm{O}_{3}+\mathrm{TOFE}\right) / \mathrm{SiO}_{2}$ show similar changes with grain-size variations, which further confirm that the whole segment is relatively evenly composed, except for some of their extreme values. In the AQS3, the graph of major elements and $\left(\mathrm{Al}_{2} \mathrm{O}_{3}+\mathrm{TOFE}\right) / \mathrm{SiO}_{2}$ values also shows considerable fluctuations.

\section{Discussion}

\section{Climate implications of grain size and major elements}

On the basis of the distributions of grain-size parameters in the AQS3, the loess in the AQS3 is inferred as aeolian sandy sediment under arid climate condition in the northern piedmont of the Kunlun Mountains during the MIS3, and its climate is similar to that of the present. Furthermore, whether the climate variations on millennial scale reflected by the changes in grain size and major elements in the AQS3 mean the cold-arid and warm-humid climate fluctuations in the overall arid environment remains poorly understood. Variations in the values of $\mathrm{Mz}$ and $\sigma$ in the AQS3 probably offer a clue to the climate fluctuation on a millennial scale. When the climate becomes

\begin{tabular}{|c|c|c|c|c|c|c|c|}
\hline Sample of layer & Thickness/cm & U/ppm & Th /ppm & $\mathbf{K} \%$ & Annual amount/m·Gy-1 & Total amount/Gy & age/ka B. P. \\
\hline 3L-XAL235 & 380 & 2.49 & 11.10 & 2.27 & 4.39 & $108.40 \pm 14.50$ & $24.70 \pm 3.10$ \\
5L-XAL234 & 660 & 2.85 & 8.36 & 1.63 & 3.81 & $106 \pm 10.60$ & $27.80 \pm 2.70$ \\
9L-BGI59* & 2540 & 1.68 & 11.20 & 2.15 & 1.29 & 46.30 & $35.80 \pm 3.60$ \\
10LVS-BGI88* & 2645 & 2.66 & 8.80 & 2.07 & 1.28 & 46.30 & $36.00 \pm 3.80$ \\
18LVS-BGI92* & 4180 & 2.20 & 7.80 & 2.13 & 1.24 & 71.30 & $57.50 \pm 6.20$ \\
\hline
\end{tabular}

*the dating error of 9L-BGI59, 10LVS-BGI88 and 18LVS-BGI92 is $5 \%$, with the ages $\pm 1.79 \mathrm{ka}, \pm 1.80 \mathrm{ka}$ and $\pm 2.87 \mathrm{ka}$

Table 1: The TL dating ages of some horizons in the AQS3 and their parameters. 
Citation: Wang F, Li B, Niu D, Wen X, Li Z, et al. (2017) Millennial-Scale Climate Variations During the MIS3 in the North Piedmont of the Kunlun Mountains, China. J Environ Anal Toxicol 7: 455. doi: 10.4172/2161-0525.1000455

Page 4 of 6

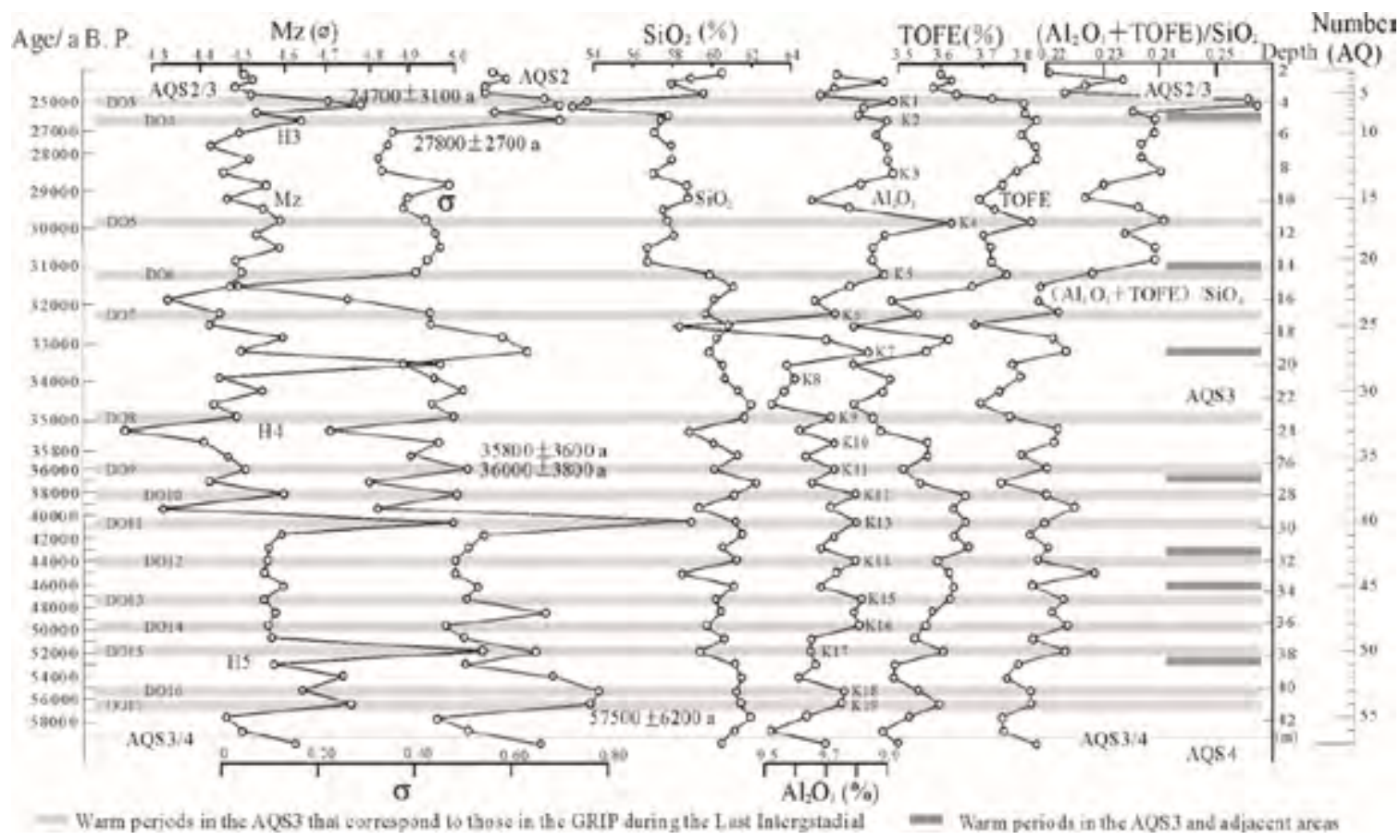

Figure 3: The distributions of the $\mathrm{Mz}$ and $\sigma$, and the major elements $\mathrm{SiO}_{2}, \mathrm{Al}_{2} \mathrm{O}_{3}$, TOFE and the $\left(\mathrm{TOFE}+\mathrm{Al}_{2} \mathrm{O}_{3}\right) / \mathrm{SiO}_{2}$ ratio in the AQS3 of the Kunlun Mountains.

warm, the wind weakens, fine particles accumulate, and grain size becomes poorly sorted. Consequently, the increase in $\mathrm{Mz}$ and $\sigma$ values indicates the warm climate. When the climate becomes cold, the wind strengthens, and the coarse particles can be blown further. Thus, the grain size becomes well sorted, and the decrease in $\mathrm{Mz}$ and $\sigma$ values reflects the cold climate. In Figure 3, the considerable oscillation of $\mathrm{Mz}$ and $\sigma$ values over time suggests the climate variations in the AQS3.

According to the changes in major elements, we believed that the continuously sedimentary sequence of the AQS3 has also recorded warm-arid or warm-humid geologic information in the overall aridcold climate. Among these changes, the variations in $\mathrm{Al}_{2} \mathrm{O}_{3}$ and TOFE reveal the millennial-scale climate fluctuations because these elements aggregate under biological and chemical weathering conditions in a warm-humid climate. In particular, the increased $\mathrm{Al}_{2} \mathrm{O}_{3}$ and TOFE contents result from the strengthened chemical weathering of warmhumid climate during the periods of loess accumulation. In Figure 3 , the $\mathrm{Al}_{2} \mathrm{O}_{3}$ and TOFE contents range within $9.5 \%-10.0 \%$ and $3.4 \%$ $3.9 \%$ with minor variations in nearly all samples, which indicates that the loess origins are relatively evenly composed. Accordingly, the alternations between the low values and high peaks of the $\mathrm{Al}_{2} \mathrm{O}_{3}$ and TOFE contents in the AQS3 result from the cold-arid and warm-humid climates. When the alternation of the peak and valley represents a cold-arid and warm-humid climate cycle, the AQS3 segment may have experienced 19 climate cycles. Both $\mathrm{Al}_{2} \mathrm{O}_{3}$ and TOFE contents display nearly the same variations. We labeled the high peaks of the $\mathrm{Al}_{2} \mathrm{O}_{3}$ or TOFE contents as $\mathrm{K} 1, \mathrm{~K} 2, \mathrm{~K} 3, \ldots$, and $\mathrm{K} 19$ to represent the warm periods; among these labels, K18 and K19 exhibit one peak but indicate two warm periods. The valleys between two high peaks represent the cold periods for accumulation of aeolian sandy dust. The variations in alternation between peaks and valleys indicate the millennial-scale climate fluctuations.

According to above evidence, many warm periods exist in the loess accumulation during the AQS3 period in the Kunlun Mountains and northern piedmont of Altunshan Mountains. The type of climate (arid-hot, arid-warm, or warm-humid) is remarkably impacted by the distance from the mountainous ice-snow areas, the precipitation from the evaporation of ice-snow, and the interaction of rivers and lakes. Arid-hot climate is helpful for glacial evaporation and precipitation within the piedmont areas. Therefore, the simultaneous existence of warm-arid and warm-humid climates but in different places is normal in this special area of the northern piedmont of Kunlun Mountains. For example, during summer, the climate is relatively warm-humid in Aqiang near the glacial but that of outside Aqiang is relatively arid-hot. The annual average precipitation of Aqiang reaches $170 \mathrm{~mm}$, whereas the annual average precipitation of northeast and northwest Aqiang gradually reduces to $50 \mathrm{~mm}$. Although the aeolian sandy loess mainly accumulates under the overall condition of cold-arid windy climate, the periods of warm-arid or warm-humid changes indicate climate fluctuations. Overall, according to the observation and studies of the loess in the northern piedmont of the Kunlun Mountains since the 1980 s $[6,12,14]$, the alternations of cold-arid and warm-humid climates actually exist in these areas.

\section{Causes of millennial-scale climate variations}

According to previous studies on the paleoenvironment in the south of Xinjiang, the fine grain in the strata serves as the indicator of warm climate since the Last Glacial or in the $10 \mathrm{ka}$-scale climate fluctuations. For example, the fine grains in the loess in the Aqiang section correspond to the paleosoil from S1 to S7 in the Loess Plateau $[15,16]$, and the light green subclay with Pianorbis sp. indicates the warm climate in the lacustrine facie with the age ranging within 70004000 a BP in Yuetegan of Hetian [12]. This finding suggests that the winter monsoon triggered by Siberia-Mongolian anticycle remarkably weakens and declines northward during those periods in the north of China. During such period, the climate is dry-warm in large areas in the south of Xinjiang, except for the region near ice-snow and river- 
Citation: Wang F, Li B, Niu D, Wen X, Li Z, et al. (2017) Millennial-Scale Climate Variations During the MIS3 in the North Piedmont of the Kunlun Mountains, China. J Environ Anal Toxicol 7: 455. doi: 10.4172/2161-0525.1000455

Page 5 of 6

lakes with warm-humid climate. Therefore, the warm periods from K1 to K19 in the AQS3 should correspond to the high peaks of $\mathrm{Mz}(\Phi)$ and $\sigma$, and the cold periods correspond to the low values of $\mathrm{Mz}$ and $\sigma$. Most peaks and valleys of $\mathrm{Al}_{2} \mathrm{O}_{3}$ and TOFE in the AQS3 correspond well to the changes in $\mathrm{Mz}$ and $\sigma$ and variation of $\left(\mathrm{Al}_{2} \mathrm{O}_{3}+\mathrm{TOFE}\right) / \mathrm{SiO}_{2}$. However, $\mathrm{SiO}_{2}$ contents show opposite variations. Some differences are also obvious, and the warm periods $\mathrm{K} 3, \mathrm{~K} 7, \mathrm{~K} 8$, and $\mathrm{K} 10$ show $\mathrm{Mz}$ valleys with uncertain peaks and valleys of $\sigma$. According to the positive relations among $\mathrm{Al}_{2} \mathrm{O}_{3}$, TOEF, $\left(\mathrm{Al}_{2} \mathrm{O}_{3}+\mathrm{TOFE}\right) / \mathrm{SiO}_{2}, \mathrm{Mz}$, and $\sigma$ and negative relations among $\mathrm{SiO}_{2}, \mathrm{Mz}$, and $\sigma$, the climate within this area changes as follows: when the cold-arid winter monsoon strengthens, the coarse grain-size sandy sediments increase, and the $\sigma$ values decrease with well-sorted feature because of the reduction of fine-grain contents. Furthermore, the sandy sediments contain debris, such as quartz and silicate minerals; the $\mathrm{SiO}_{2}$ contents increase, whereas those of $\mathrm{Al}_{2} \mathrm{O}_{3}$ and TOFE decrease. On the contrary, when the winter monsoon weakens and moves northwards, large areas of Taklimakan Desert, including the Aqiang region, are under the control of arid-hot hot-low pressure because the in land location is surrounded by mountains and plateaus. Thus, the heat strength forces the evaporation and melting of ice-snow in the Kunlun Mountains and northern piedmont of the Altunshan Mountains, which results in the increased precipitation and flowing water in the regions in front of the mountains. Consequently, the warm-humid climate exists in certain areas of the piedmont under the overall arid-hot climate during the AQS3 period. Therefore, the $\mathrm{Mz}$ and $\sigma$ values increase, and the $\mathrm{SiO}_{2}$ contents decrease because of the weakened wind force in Aqiang. In addition, the biochemical weathering strengthens, and the contents of $\mathrm{Al}_{2} \mathrm{O}_{3}$ and TOFE and $\left(\mathrm{Al}_{2} \mathrm{O}_{3}+\mathrm{TOFE}\right) / \mathrm{SiO}_{2}$ ratio increase because of the warm-humid climate in the areas of glacier foothills.

\section{Comparison of climate variation on a millennial scale}

Since Heinrich first discovered the large-scale Heinrich Events $[25,26]$ in the North Atlantic in 1988, millennial-scale climate variations during the MIS3 in the North Hemisphere are continuously confirmed in different places, such as in Greenland [26], North Pacific [27], West Pacific [24], and Arab Sea [28] in the north of Indian Ocean. In recent years, some Chinese researchers continuously found millennial-scale climate fluctuations during the MIS3 from the records in the ice-core of the Qinghai-Tibet Plateau [29], lakes [30], loess [31], and stalagmite [32]. Many studies suggested that the MIS3 in China is a warm period with special climate. During this period, high temperature and precipitation result in MegaLake period of Qinghai-Tibet Plateau [33], Tonggeli MegaLake period of Alashan Plateau [34], and in many hightemperature precipitation events in the Mu Us Desert [35]. However, in addition to the recent study on the paleoclimate of low-lying land in Luobupo on the east edge of the Tarim Basin since $30 \mathrm{ka} \mathrm{B}$. P., studying the mechanism of on environmental changes in the Tarim Basin in the hinterland of Center Asian during the MIS3 requires exclusive studies. Thus, variations in the grain-size parameters and major elemental contents in the AQS3 of the north piedmont of Kunlun Mountains are important geological evidence for studying environment evolutions in the Tarim Basin.

Millennial-scale climate variations during the MIS3 were mostly reported from the record of ice-core oxygen isotope in the GRIP, namely, the D/O oscillation, which recorded about 15 cold-warm oscillations. Among these records, the ages of the warm periods from $\mathrm{D} / \mathrm{O} 3$ to $\mathrm{D} / \mathrm{O} 17$ are $25,26,29,31,32,35,37,38,39,43,46,51,53,56$, and $57 \mathrm{ka}$, respectively. Except for K3, K7, K8, and K10 in the AQS3, the remaining 15 warm periods within the section could correspond to those from $\mathrm{D} / \mathrm{O} 3$ to $\mathrm{D} / \mathrm{O} 17$. Some ages, such as the ages of $\mathrm{K} 1$ and $\mathrm{D} /$ O3, $\mathrm{K} 2$ and $\mathrm{D} / \mathrm{O} 4, \mathrm{~K} 5$ and $\mathrm{D} / \mathrm{O} 6, \mathrm{~K} 9$ and $\mathrm{D} / \mathrm{O} 8$, and $\mathrm{K} 12$ and $\mathrm{D} / \mathrm{O} 10$, are nearly the same.

In addition to the correlations of the warm periods, the cold events $\mathrm{H} 3, \mathrm{H} 4$, and H5 occurring in 27, 35.5 Bond et al. and 52 ka Heinrich in the North Atlantic, respectively, also present good correlations with those recorded by the low values of $\mathrm{Mz}$ and $\sigma$ in the AQS3 during the Last Interglacial and the low values of $\mathrm{Al}_{2} \mathrm{O}_{3}$ and TOFE contents. This finding indicates that the winter monsoon is relatively strong, and the particles are coarse on the ground surface, with high sorted degree in the northern piedmont of Kunlun Mountains.

\section{Conclusion}

The warm periods recorded at the AQS3 segment in the north piedmont of the Kunlun Mountains and its adjacent areas and the close relationship with ice-core oxygen isotope records of the GRIP and GRIP2 in Greenland suggest that climate fluctuations in the Kunlun Mountains are eventually subjected to the D/O oscillation from the North Hemisphere in the MIS3. Their forming mechanisms are also probably the same. The AQS3 segment presents slight variations in $\mathrm{Mz}, \sigma$, and major elements mainly because of the high sea level and its location near the glaciers with weak chemical weathering in short period. The high-resolution climate variations on a millennial scale are also sensitively preserved. Moreover, the millennial-scale climate fluctuations in the alternation of cold-arid and warm-humid climate may represent the special regional climate changes triggered by global climate variations near the glaciers in the north piedmont of the Kunlun Mountains during the MIS3. The millennial-scale climate variations are regional responses to the global climate changes during the MIS3.

\section{Acknowledgements}

This paper funded by Doctoral Research Program of Huizhou University, Grunt Number: C 13.0203; National Basic Research Program of China, Grunt Number: 2013СB955903; National Natural Sciences Foundation of China, Grant Number: 41290250; National Natural Sciences Foundation of China, Grant Number: 41371208

\section{References}

1. Obruchev VA (1958) The problem of sand and loess. Translated by Lezhu and Liu Tongsheng, Industry Press, Beijing, pp: 205-251.

2. Tingru $Z$ (1963) Main types of terrestrial facies deposition and the relationship with climatic development. Acta Geographica Sinica 29: 109-129.

3. Liu TS (1965) Loess accumulations in China. Science Press, Beijing, China

4. Zheng W (1981) Approach to the genesis of the Taklamakan Deser. Acta Geographica Sinica 36: 280-291.

5. Li BS, Jin J (1988) A preliminary research on the Pulu stratigraphic section in the sandy hills on the southern border of the Taklimakan Desert. Chinese Science Bulletin 33: 140-143.

6. Baosheng L, Guangrong D, Yajun S, Jianyou S, Shangyu G, et al. (1989) Preliminary observation and research on the loess in the north piedmont of the Kunlun Mountains south of Pulu, Xingjiang. Geological Review 35: 423-429.

7. Zheng BX, Jiao KQ, Li SJ (1990) A new progress of the Quaternary glacial study of Qinghai-Tibet Plateau, taking study of the west Kunlun Mountain as an example. Chinese Science Bulletin 35: 533-537.

8. Gao CH, Zhang QS (1991) On loess deposits at the north side of the Kunlun Mountains and environmental evolution during the Late Quaternary. In: Xinjiang Institute of Geography, Chinese Academy of Sciences. Contributions to Geography of Arid Areas, pp: 23-30.

9. Hövermann J, Hövermann E (1991)Pleistocene and Holocene geomorphological features between the Kunlun Mountains and the Taklimakan Desert 6: 51-72.

10. Wang FB (1992) Dust deposition on Kalakunlun and Kunlun Mountains. In Liu TS, Loess ZS (eds.), Quaternary Geology, Globe Change. Science Press, 
Citation: Wang F, Li B, Niu D, Wen X, Li Z, et al. (2017) Millennial-Scale Climate Variations During the MIS3 in the North Piedmont of the Kunlun Mountains, China. J Environ Anal Toxicol 7: 455. doi: 10.4172/2161-0525.1000455

Page 6 of 6

Beijing, China, pp: 108-115

11. Li BS, Dong GR, Zhu YZ, Li S, Ren XS (1993) Sedimentary environment evolution on the desert and loess in Tarim Basin since the last glacial age. Science in China 23: 644-651.

12. Wen QZ, Qiao YL (1995) The palaeoclimatic records in sediments of the northern slop of Kunlun Mt. since the Late Pleistocene. In: China's Society of the Qinghai-Tibetan Plateau Research. Qinghai-Tibetan Plateau and Global Varitions-Proceedings of Symposia (1993 and 1994) Meteorological Press of China, Beijing, pp: 96-104.

13. Baosheng L, Guangrong D, Jiasheng Z, Sen L, Heling J (1995) Aeolian facies belts in the Taklimakan Desert. Acta Geologica Sinica 8: 317-328.

14. Yajun S, Baosheng $L$ (1995) Sporo-pollen assemblage in the loess of Upper Reach of the Keriya River and its environment. Journal of Desert Research 15: $37-41$.

15. Baosheng L, Sen L, Yue W, Guangrong D, Heling J (1998) Geological age of the sand and dust deposits of the Aqiang section in the extremely arid region of China. Acta Geologica Sinica 72: 83-92.

16. Fang X, Lü L, Yang S, Li J, An Z, et al. (2002) Loess in Kunlun Mountains and its implications on desert development and Tibetan Plateau uplift in West China. Science in China (Series D) 45: 289-299.

17. Sun J, Liu T (2006) The age of the Taklimakan Desert. Science 312: 1621.

18. Sun J, Zhang Z, Zhang $L$ (2009) New evidence on the age of the Taklimakan Desert. Geology 37: 159-162.

19. Zan J, Fang X, Nie J, Yang S, Song C, et al. (2010) Magnetic properties of surface soils across the southern Tarim Basin and their relationship with climate and source materials. Chinese Science Bulletin 55: 1-7.

20. Krumbein WC (1934) Size frequency distribution of sediments. Journal of Sedimentary, Petrology 4: 65-77.

21. Martinson DG, Pisias NG, Hays JD, Imbrie J, Moore TC, et al. (1987) Age dating and the orbital theory of the Ice ages: Development of a high-resolution 0 to 300,000 year chronostratigraphy. Quaternary Research 27: 1-29.

22. Anklin M, Barnola JM, Beer J, Blunier T, Chappellaz J, et al. (1993) Climate instability during the last interglacial period recorded in the GRIP ice core. Nature 364: 203-207.
23. Dansgaard W, Johnsen SJ, Clausen HB, Hvidberg CS, Steffensen JP (1993) Evidence for general instability of past climate from a 250-kyr ice-core record. Nature 364: 218-220.

24. Linsley BK (1996) Oxygen-isotope record of sea level and climate variations in the Sulu Sea over the past 150000 years. Nature 380: 234-237.

25. Heinrich $H$ (1988) Origin and consequence of cyclic ice-rafting in the Northeast Atlantic Ocean during the past 130000 years. Quaternary Research 29: 142-152.

26. Folk RL, Ward WC (1957) Brazos Reviver bar: A study in the significance of grain size parameters. Journal of Sedimentary Petrology 27: 3-26.

27. Heusser $L$ (1998) Direct correlation of millennial-scale changes in the western North American vegetation and climate with changes in the California current system over the past 60000 years. Paleoceanography13: 252-262.

28. Leuschner DC, Sirocko F (2000) The low-latitude monsoon climate during Dansgaard-Oeschger cycles and Heinrich events. Quaternary Science Review 19: 243-254

29. Yao TD, Thompson LG, Shi YF, Jiao KQ, Zhang XP (1997) A study on the climate changes from Guliya ice core records since Last Interglacial Period. Science in China (Series D) 27: 447-452.

30. Li B (2000) The last greatest lakes on the Xizang (Tibetan) Plateau. Acta Geographica Sinica 55: 174-182.

31. An Z (2000) The history and variability of the East Asian paleomonsoon climate. Quaternary Science Review 19: 171-178.

32. Wang YJ, Cheng H, Edwards RL, An ZS, Wu JY, et al. (2001) A high-resolution absolute-dated Late Pleistocene monsoon record from Hulu Cave, China. Science 294: 2345-2348.

33. Zhang HC, Peng JL, Ma YZ, Chen GJ, Feng ZD, et al. (2004) Late Quaternary palaeolake level in Tengger Desert, NW China. Palaeogeography, Palaeoclimatology, Palaeoecology 211: 45-58.

34. Wen X, Li B, Zheng Y, Zhang DD, Ye J (2009) Climate variability in the Salawusu River valley of the Ordos Plateau (Inner Mongolia, China) during Marine Isotope Stage 3. Journal of Quaternary Science 24: 61-74.

35. Chao L, Dong Y, Zicheng P, Zhao-Feng Z, Wei-Guo L (2007) Climatic and environmental records in the sediment of the Luobei billabong in Lop-Nur, Xinjiang in recent 32 ka. Quaternary Sciences 27 : 114-121. 